\title{
Observations on associated histopathology with Aggregata octopiana infection (Protista: Apicomplexa) in Octopus vulgaris
}

\author{
C. Gestal*, E. Abollo, S. Pascual \\ Area de Parasitología. Grupo FEPMAR-PB2, Facultad de Ciencias, Universidad de Vigo, Apartado 874, 36200 Vigo, Spain
}

\begin{abstract}
Gamogony and sporogony of Aggregata octopiana were commonly observed during histological examination of the digestive tract of wild Octopus vulgaris from Ría de Vigo (NW Spain). A. octopiana infected noncuticularized caecum and intestine, and cuticularized oesophagus and crop. Infection was also observed in the gills and in covering mesenterium, mainly of the digestive gland and gonad. Histological and ultrastructural lesions associated with A. octopiana included host cell hypertrophy with nuclear displacement, inflammation, phagocytosis, ulceration and destruction of organ architecture. The possible existence of a malabsorption syndrome in the host is deduced.
\end{abstract}

KEY WORDS: Apicomplexa - Aggregata octopiana - Octopus vulgaris - Digestive tract · Histopathology $\cdot$ Defense mechanisms

\section{INTRODUCTION}

Coastal octopuses have the longest history of human exploitation of any cephalopod (Boyle 1990). The best known species, the common octopus Octopus vulgaris Cuvier, 1798, is extremely important in fisheries (Roper et al. 1984, Balguerías et al. 2000, Domain et al. 2000, Josupeit 2000, Pereira [www.fao.org/docrep/X3900e/ $\mathrm{X} 3900 \mathrm{e} 9 \mathrm{htm}]$ ), and also has great potential as an aquaculture species. It also represents a major protein resource in most Mediterranean countries (Guerra 1992, Quetglas et al. 1998) and is widely used as a biomedical research model (Hanlon \& Forsythe 1985).

Despite their importance, little information is available on protozoan-related diseases occurring in wild octopus populations. A notable exception is the coccidian Aggregata Frenzel, 1885 (Apicomplexa: Aggregatidae) that has been reported in the digestive tract of 7 octopus species world-wide (Gestal 2000).

Coccidians within the genus Aggregata are intracellular parasites with a 2-host life-history that are

\footnotetext{
*Present address: Grupo Ecobiomar, Instituto de Investigaciones Marinas (CSIC), Eduardo Cabello 6, 36208, Vigo, Spain.E-mail: cgestal@iim.csic.es
}

transmitted through the food-web. Sexual stages occur in the digestive tract of cephalopod, the definitive host; asexual stages infect the digestive tract of crustaceans, the intermediate hosts (Hochberg 1990).

The presence and taxonomic identification of the genus Aggregata in cephalopods have been recorded by different authors (Moroff 1908, Dobell 1925, Narasimhamurti 1979, Sardella \& Re 1988, Poynton et al. 1992, Estévez et al. 1996, Gestal et al. 1999). Observations on associated pathology of Aggregata infections in cephalopods is limited to A. dobelli and $A$. millerorum parasites of Octopus dofleini and O. bimaculoides respectively (Poynton et al. 1992).

Histological and ultrastructural lesions associated with Aggregata octopiana (Schneider 1875) in the digestive tract of Octopus vulgaris from the NE Atlantic coast are described herein.

\section{MATERIALS AND METHODS}

A total of 100 post-recruit common octopuses Octopus vulgaris was collected by traps in the Ría de Vigo, Galicia, Spain (NE Atlantic Ocean: 42 $2^{\circ} 15^{\prime} \mathrm{N}, 8^{\circ} 48^{\prime} \mathrm{W}$ ). At the laboratory, fresh individuals in post-mortem 
condition were necropsied. To confirm the presence of Aggregata octopiana oocysts, squash preparations of fresh material from all organs of the paleal cavity were analysed by light microscopy (LM). Infected tissue samples from target organs (caecum and intestine) were then fixed in $10 \%$ buffered formalin, dehydrated in a graded ethanol series, embedded in paraffin and sectioned using a Microm HM-340 E microtome (Microm). Sections (4 to $5 \mu \mathrm{m}$ ) were stained with hematoxylin-eosin following standard procedures (Culling et al. 1985).

Ultrastructural aspects of infected tissues were assessed by transmission electron microscopy (TEM). Small pieces of infected tissues were collected and fixed in $2.5 \%$ glutaraldehyde in $0.1 \mathrm{M}$ sodium cacody-

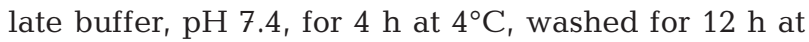
$4{ }^{\circ} \mathrm{C}$ in the same buffer, and post-fixed in buffered $2 \%$ $\mathrm{OsO}_{4}$ for $3 \mathrm{~h}$ at the same temperature. After dehydration in a graded ethanol series, the tissue was embedded in Spurr resin. Semi-thin sections obtained by diamond knife were stained with methylene blue. Ultrathin sections were double stained with uranyl acetate and lead citrate, and observed using a JEOL 100CXII TEM operated at $60 \mathrm{kV}$.

\section{RESULTS}

Gross pathology. White cysts containing Aggregata octopiana sporocysts were commonly found by gross observation in the digestive tract.

Site of infection. As seen by LM, the noncuticularized spiral caecum and intestine were the most infected organs, although infection also extended to the cuticularized crop and oesophagus (including the region adjacent to the radula). In massive infections, gill tissue and the covering mesenterium, mainly of the digestive gland and gonad, were also infected. Fig. 1 shows the relative percentage of the infected organs.

Prevalence. Of the octopuses examined, $98 \%(98 / 100)$ were infected at least in the caecum tissue.

Histopathology. In the target organs (caecum and intestine), parasites were most frequently found in the submucosa and muscularis, less commonly in the serosa.

Parasite development in the octopus includes gamogony, and sporogony. After fertilisation, formation of the zygote occurs, and a gross cyst wall develops. Invaded host cells undergo

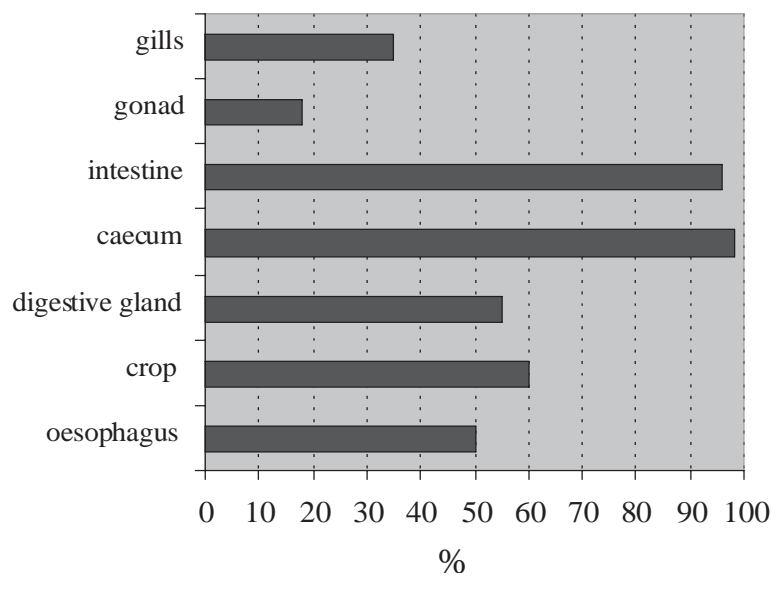

Fig. 1. Octopus vulgaris. Relative percentage of organs infected with Aggregata octopiana

considerable hypertrophy, and the nucleus appears to be displaced to one side (Fig. 2). Infection starts in the mucosal folds and spreads to the proximal submucosa and serosa layers. Frequently, marked distension of the infected tissue area due to the development of gametes or sporogonic stages is seen, causing rupture of the basal membrane and the detachment of the epithelial cells (Fig. 3A,B,C). Due to severe loss of epithelial cells, atrophy of mucosal folds occurrs in affected intestine and caecum. The mucosa of the caecum and intestine is ulcerated. Inflammation, pericyst reactions of connective tissue and infiltration of hemocytes in the area of ulcerated mucosa is observed (Fig. 3D,E,F). Fibrosis and necrosis are also occasionally observed. Finally, infected mucosal cells undergo

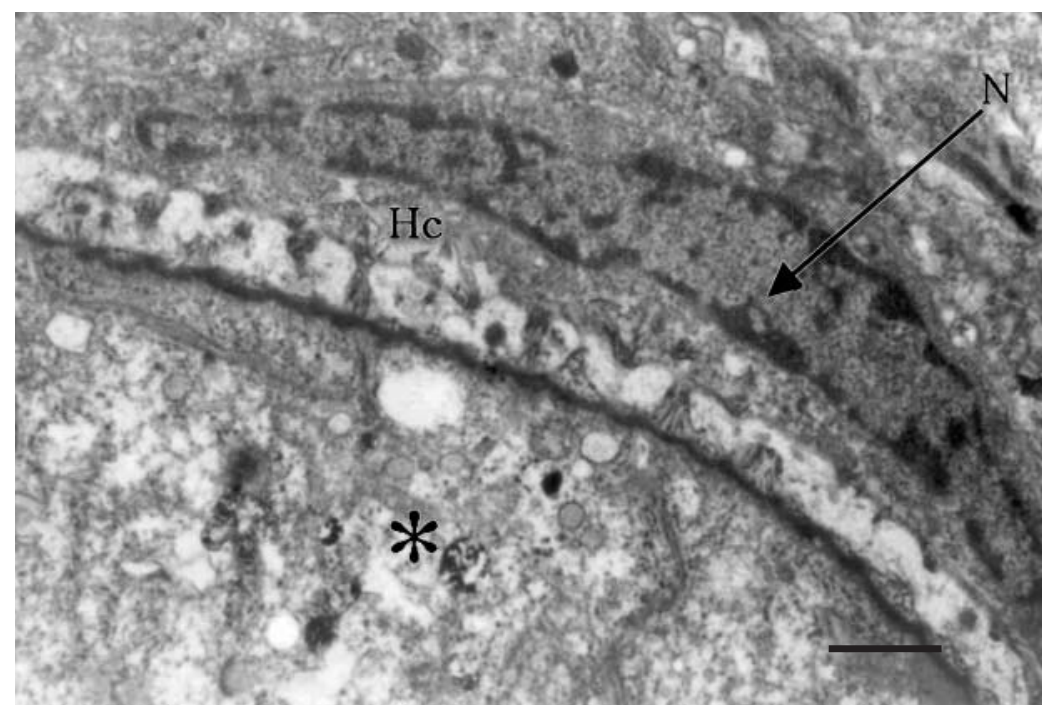

Fig. 2. Octopus vulgaris. TEM micrograph of a hypertrophied host cell (Hc) of the caecum infected by Aggregata octopiana (*). Arrow shows the cellular nucleus $(\mathrm{N})$ displaced to one side of the cell. Scale bar $=1.30 \mu \mathrm{m}$ 
necrosis. Different stages of gamogony and sporogony are observed in the caecum and intestine. Individual sporocysts not enclosed in cysts are present in the tissue. Sporogonic stages are phagocytosed by hemocytes (Fig. 4A,B). In heavy infections, most infected host tissue is replaced by parasites. Loss of intestinal epithelium and destruction of the tissue organ architecture is observed (Fig. 4C,D).

\section{DISCUSSION}

Although an extensive literature dealing with diseases and defense mechanisms is available for other commercially important molluscs, little emphasis has been placed on parasite-caused diseases, pathological effects of parasites, and defense-associated responses of cephalopods against specific pathogens (Hochberg 1990, Ford 1992).

Molluscs have both cellular and humoral mechanisms of defense (Ford 1992). The most widely reported defense mechanism in cephalopods is the cellular one (Malham 1996, Malham et al. 1997, Malham \& Runham 1998). Hemocytes are important in phagocytosis and killing of infectious agents, and in the repair of tissue damage resulting from mechanical or biological trauma. Encapsulation and phagocytosis of foreign
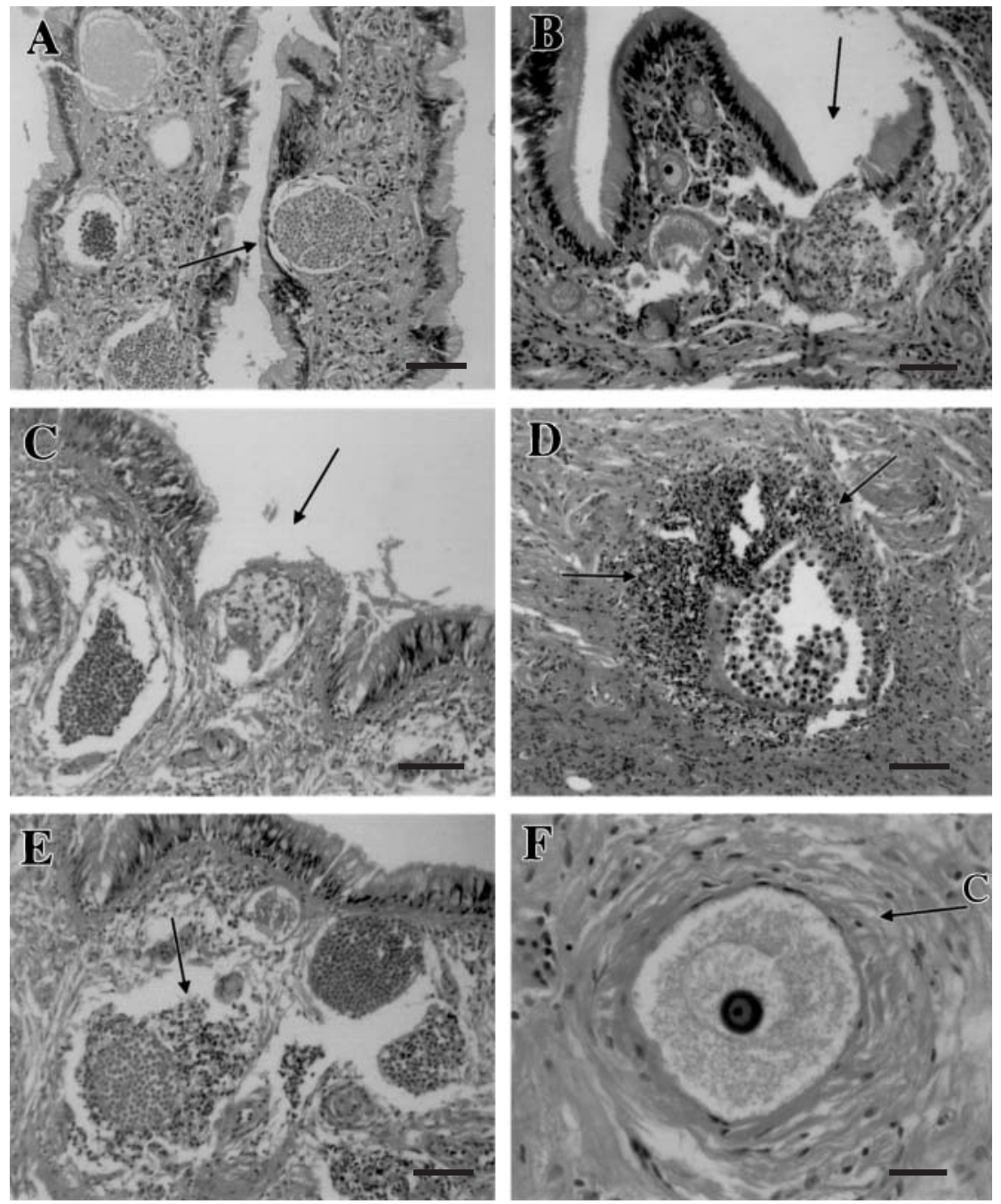

Fig. 3. Octopus vulgaris. Histological sections of the caecum and intestine infected with Aggregata octopiana. (A) Caecum villus infected with A. octopiana showing distension (arrow). Scale bar $=100 \mu \mathrm{m}$. $(\mathrm{B}, \mathrm{C})$ Distension and rupture of infected tissue from development of the coccidia; arrows show rupture of the basal membrane and loss of epithelial cells. Scale bars = (B) $100 \mu \mathrm{m}$, (C) $60 \mu \mathrm{m}$. (D), (E) Inflammatory reaction in response to the A. octopiana infection; arrows show strong infiltration of hemocytes surrounding A. octopiana. Scale bar $=100 \mu \mathrm{m}$. (F) Pericyst reaction (C) of connective tissue surrounding the parasite. Scale bar $=40 \mu \mathrm{m}$

materials are primary roles of molluscan hemocytes (Ford 1992). Phagocytosis of foreign material has been described in coccidian infections in different marine host species (Lom \& Dyková 1992) and birds (Hammond 1973).

The degree of damage caused by coccidia to their hosts depends upon the numbers of parasites occurring at any particular site. Thus, the degree of damage to the host caused by coccidia might be considered directly proportional to the degree of destruction of host cells. Long (1973) showed that there is a clear relation between the pathogenicity of coccidian species and the depth to which they penetrate the intestinal mucosa of the host. Hammond (1973) described the pathologic effects of the coccidia genus Eimeria, showing a strong inflammatory infiltration and deformation of the intestinal villus of the host caused by the infection.

The first signs of pathology in the cephalopod intestinal infections by the genus Aggregata occur at the point of entry and during migration of the parasite through epithelial cells. This is due to the break of the junctions between cells, causing necrosis (Dobell 1925, Porchet-Henneré et al. 1981, Hochberg 1990). Dobell (1925) described by LM the destructive effects of $A$. eberthi infections in Sepia officinalis, and host cellular defense reactions against infection. This author indi- 

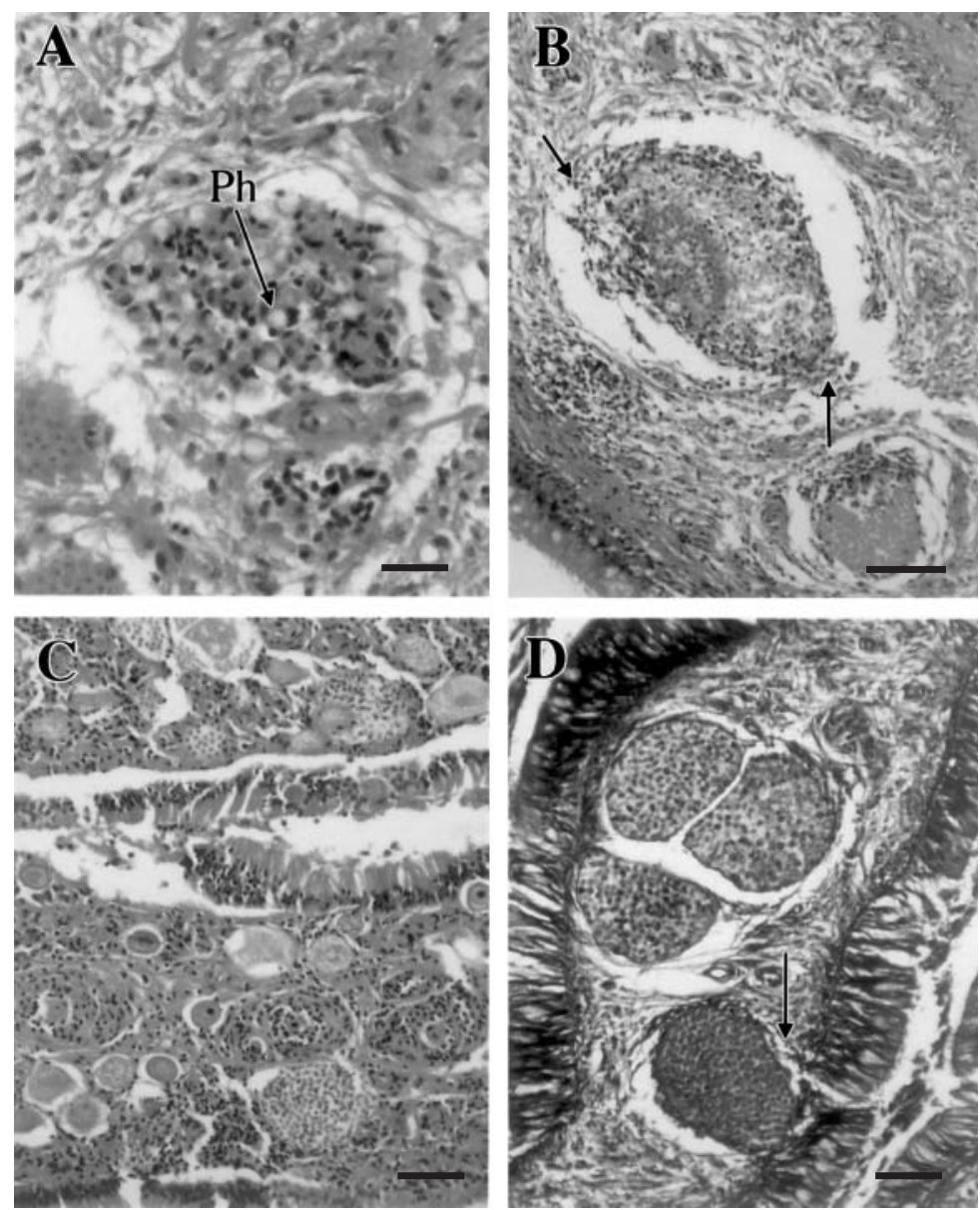

Fig. 4. Octopus vulgaris. Histological sections of the caecum and intestine infected with Aggregata octopiana. (A,B) Infected intestinal tissue showing A. octopiana sporocysts phagocytosed by hemocytes (Ph) (arrows). Scale bars $=(A) 40 \mu \mathrm{m},(B) 60 \mu \mathrm{m}$. (C,D) Infected caecum showing distension (arrow in D) and destruction of the tissue organ architecture; the majority of heavily infected caecum area is replaced by parasites. Scale bar $=100 \mu \mathrm{m}$

trast, Poynton et al. (1992) indicated that gamogony and sporogony of A. millerorum occurred in the noncuticularized spiral caecum and intestine, and in the cuticularized oesophagus and crop of cephalopod hosts. However, another species, A. dobelli was exclusively present in noncuticularized portions of the digestive tract of its cephalopod host. The presence of $A$. millerorum in cuticularized portions of the digestive tract was interpreted by Poynton et al. (1992) as an increase of the invasive potential of this Aggregata species. Our results are not in complete agreement with the interpretation of Poynton et al. (1992). Although A. octopiana also has strong invasive potential, a high relationship between invasiveness and infection intensity should also be noted. Thus, heavily infected octopuses had a higher number of different infected organs (noncuticularized and cuticularized organs) than less infected octopuses (noncuticularized organs only).

Pathology caused by different Aggregata species in their cephalopod hosts is highly variable. These effects probably depend not only on the cephalopod host but also on the Aggregata species. Although we did observe signs of host defense, the host response of Octopus vulgaris to the $A$. octopiana infection appears limited. A limited defense response was also described by Poynton et al. (1992) for $A$. dobelli and A. millerorum in octopuses from Pacific waters.

Although infection by Aggregata octopiana is not believed to be the primary cause

cated that in heavily infected cuttlefish the destruction of the gut mucosal membrane occurs, and most necrotic epithelium is shed into its lumen. Sheets of necrotic intestinal epithelium and mucous membrane leave the host with the faeces (Dobell 1925). In the present study, the use of wild individuals in post-mortem condition did not allow observation of any parasitized necrotic intestinal sheets leaving the host with the faeces. However, the histopathological results herein reported suggests that the effect of A. octopiana on Octopus vulgaris was similar or even greater than that described by Dobell in $S$. officinalis.

Parasitic forms of the genus Aggregata had previously been described exclusively in the epithelial cells of the mucosa and submucosa tissue of the intestine and caecum of infected cephalopods (Dobell 1925, Porchet-Henneré et al. 1981, Hochberg 1990). In conof host death in the present study, severe Aggregata octopiana infections may have weakened the octopuses, making them more vulnerable to other biotic and abiotic effects.

Even though gross clinical signs of disease were not evident in infected live octopuses (Gestal et al. unpubl. data), a high degree of invasiveness and pathogenicity by Aggregata octopiana may have detrimental effects on gastrointestinal function. A malabsorption syndrome is probably produced in the host through the destruction of the gut architecture. Therefore, the use of biochemical analyses to determine the effect of coccidiosis on the degree of activity of absorption enzymes and physiological characteristics including the condition, growth rate, nutrient assimilation and protein/energy ration of cephalopod hosts would be useful. 
Acknowledgements. The authors thank Dr. Angel Guerra (Grupo Ecobiomar, Instituto de Investigaciones Marinas de Vigo [CSIC], Vigo, Spain) for his interesting and helpful comments during the preparation of the final draft, and Professor Carlos Azevedo (Instituto de Ciencias Biomedicas de Abel Salazar, Porto, Portugal) for his help in the TEM study. This work was partially supported by the Ministerio de Educación y Ciencia and Universidade de Vigo under the projects CICYT (MAR-1909-C05) and 64102C021.

\section{LITERATURE CITED}

Balguerías E, Quinteiro ME, Hernández-González CL (2000) The origin of the Saharan Bank cephalopod fishery. ICES J Mar Sci 57:15-23

Boyle PR (1990) Cephalopod biology in the fisheries context. Fish Res (Amst) 8:303-321

Culling CFA, Allison RT, Barr W T (1985) Cellular pathology techniques. Butterworth \& Co, London

Dobell CC (1925) The life-history and chromosome cycle of Aggregata eberthi (Protozoa: Sporozoa: Coccidia). Parasitology 17:1-136

Domain F, Jouffre D, Caverivière A (2000) Growth of Octopus vulgaris from tagging in Senegalese waters. J Mar Biol Assoc UK 80:699-705

Estévez J, Pascual S, Gestal C, Soto M, Rodríguez H, Arias C (1996) Aggregata octopiana (Apicomplexa: Aggregatidae) from Octopus vulgaris off NW Spain. Dis Aquat Org 27: 227-231

Ford L (1992) Host defense mechanisms of cephalopods. Annu Rev Fish Dis 1:25-41

Gestal C (2000) Epidemiología y patología de las coccidiosis en cefalópodos. Tesis Doctoral, Universidad de Vigo

Gestal C, Pascual S, Corral L, Azevedo C (1999) Ultrastructural aspects of the sporogony of Aggregata octopiana (Apicomplexa, Aggregatidae), a coccidian parasite of Octopus vulgaris (Mollusca, Cephalopoda) from NE Atlantic Coast. Eur J Protistol 35:417-425

Guerra A (1992) Cephalopod resources of the world: a present day view. Squid'91 Madrid International Cephalopod Trade Conference Proceedings. Agra Europe, London

Hammond DM (1973) Life cycles and development of Coccidia. In: Hammond DM, Long PL (eds) The Coccidia. University Park Press, Baltimore and Butterworths, London, p 45-79

Hanlon RT, Forsythe JW (1985) Advances in the laboratory

Editorial responsibility: Albert Sparks,

Seattle, Washington, USA culture of octopuses for biomedical research. Lab Anim Sci 35: 33-40

Hochberg FG (1990) Diseases of Mollusca: Cephalopoda. Diseases caused by protistans and metazoans. In: Kinne O (ed) Diseases of marine annimals, Vol III. Biologische Anstalt Helgoland, Hamburg, p 47-227

Josupeit H (2000) Los mercados mundiales de cefalópodos. In: Ayala C (ed) Productos del mar. $6^{\circ}$ Conferencia Internacional del Comercio de los Cefalópodos. Madrid, p 43-48

Lom J, Dyková I (1992) (ed) Protozoan parasites of fishes. Elsevier Science BV, Amsterdam

Long PL (1973) Pathology and pathogenicity of coccidial infections. In: Hammond DM, Long PL (eds) The Coccidia. University Park Press, Baltimore and Butterworths, London, p 253-294

Malham SK (1996) Inmunobiology of Eledone cirrhosa (Lamarck) PhD thesis, University of Wales, Bangor

Malham SK, Runham NW (1998) Cephalopod biodiversity, ecology and evolution. S Afr J Mar Sci 20:385-391

Malham SK, Dunham NW, Secombes CJ (1997) Phagocytosis by hemocytes from the lesser octopus Eledone cirrhosa. Iberus 15(2):1-11

Moroff T (1908) Die bei den Cephalopoden vorkommenden Aggregataarten als Grundlage einer kritischen Studie über die Physiologie des Zellkernes. Arch Protistenkd 11: $1-224$

Narasimhamurti CC (1979) The eimeriid Aggregata kudoi n. sp. from Sepia eliptica. Angew Parasitol 20:154-158

Porchet-Henneré E, Richard A, Ferreira E (1981) Contamination expérimentale in vivo et in vitro par Aggregata eberthi: etude ultraestructurale. J Protozool 28:228-239

Poynton S, Reimschuessel R, Stoskopf K (1992) Aggregata dobelli n. sp. and Aggregata millerorum n. sp. (Apicomplexa: Aggregatidae) from two species of octopus (Mollusca: Octopodidae) from the Eastern North Pacific Ocean. J Protozool 39:248-256

Quetglas A, Francesc A, Carbonell A, Merella P, Sánchez P (1998) Biology and fishery of Octopus vulgaris Cuvier, 1797, caught by trawlers in Mallorca (Balearic Sea, Western Mediterranean). Fish Res (Amst) 36:237-249

Roper C, Sweeney MJ, Nauen CE (1984) FAO species catalogue, Vol 3. Cephalopods of the world. An annotated and illustrated catalogue of species of interest to fisheries. FAO Fish Synop 125

Sardella N, Re E (1988) Parasitosis por coccidios del género Aggregata en pulpos costeros patagónicos. 1. Aggregata sp. en Octopus tehuelchus D'orbigny. Physis Secc A Oceanos Org 46(111):51-60

Submitted: April 26, 2001; Accepted: December 13, 2001

Proofs received from author(s): May 31, 2002 